DR. KYLIE SOANES (Orcid ID : 0000-0002-2266-9392)

3

4

5

6

7

Article type : Invited Review

\title{
How to work with children and animals: A guide for school-based citizen science in wildlife
} research

Kylie Soanes ${ }^{1 *}$, Kate Cranney ${ }^{2}$, Marie C. Dade ${ }^{3}$, Amy M Edwards ${ }^{4}$, Ravindra Palavalli-Nettimi ${ }^{5}$ and Tim S. Doherty 6

1 School of Ecosystem and Forest Sciences, The University of Melbourne, Parkville, Victoria, 3010 2 Centre of Excellence for Biosecurity Risk Analysis, The University of Melbourne, Parkville, Victoria, 3010 [Current address: CSIRO, Research Way, Clayton, Victoria, 3168] 3 School of Earth and Environmental Sciences, The University of Queensland, St Lucia, Queensland, 4072, Australia [Current address: Department of Geography, McGill University, Montreal, QC H3A 0B9, Canada]

4 Department of Ecology, Environment and Evolution, La Trobe University, Bundoora, Victoria, 3086 [Current address: New South Wales National Parks and Wildlife Service, Dubbo, New South Wales.] 5 Department of Biological Sciences, Macquarie University, Sydney, NSW, 2109

6 Centre for Integrative Ecology, School of Life and Environmental Sciences (Burwood Campus), Deakin University, Geelong, Victoria, 3126, Australia

*corresponding author: ksoanes@unimelb.edu.au

\section{Acknowledgements}

Thanks to Angela Moles, Erin Roger, the CSIRO Scientist in Schools program, the New South Wales Office of Environment and Heritage, and the Ecological Society of Australia for their support and giving us the opportunity to conduct this work. We thank all of the schools, teachers and most importantly, the dedicated and enthusiastic students who participated in the project. Specifically, we thank the following teachers and their respective classes: Agatha Blatti, Coburg West Primary School; Janine Hannant, Lake Clarendon State School; Jenna Farrington and Thomas Norris, Montmorency South Primary School; Margaret Kroeger, Northside Montessori School; Ainslie Peszynski, Wattle Park Primary School; and, Melinda and Jacinta Cashen, Princes Hill Primary.

\section{Ethics and funding declarations}

This work was carried out with approval from The University of Melbourne Animal Ethics Committee (1714137.1) and Macquarie University Animal Ethics Committee (2017/009). Funding was received from the New South Wales Office of Environmental Heritage and Ecological Society of Australia. Kylie Soanes is supported by the Clean Air and Urban Landscapes Hub and Threatened Species Recovery Hub of the National

This is the author manuscript accepted for publication and has undergone full peer review but has not been through the copyediting, typesetting, pagination and proofreading process, which may lead to differences between this version and the Version of Record. Please cite this article as doi: $10.1111 /$ AEC.12836 
Environmental Science Program. Amy Edwards is supported by a School of Life Sciences, La Trobe University Post-doctoral Fellowship.

\section{Abstract}

Engaging school students in wildlife research through citizen science projects can be a win-win for scientists and educators. Not only does it provide a way for scientists to gather new data, but it can also contribute to science education and help younger generations become more environmentally aware. However, wildlife research can be challenging in the best of circumstances, and there are few guidelines available to help scientists create successful citizen science projects for school students. This paper explores the opportunities and challenges faced when developing school-based citizen science projects in wildlife research by synthesising two sources of information. First, we conducted a small, school-based citizen science project that investigated the effects of supplementary feeding on urban birds as a case study. Second, we reviewed the literature to develop a database of school-based citizen science projects that address questions of wildlife ecology and conservation. Based on these activities, we present five lessons for scientists considering a school-based citizen science project. Overall, we found that school-based citizen science projects must be carefully designed to ensure reliable data is collected, students remain engaged, and the project is achievable under the logistical constraints presented by conducting wildlife research in a school environment. Ultimately, we conclude that school-based citizen science projects can be a powerful way of collecting wildlife data while also contributing to the education and development of environmentally aware students.

Key words: citizen science, urban biodiversity, school students, environmental education, bird feeding, Introduction

Researchers within the fields of ecology and conservation have embraced citizen science for its potential to generate scientific knowledge, engage the community in environmental issues, and foster connection to nature (Dickinson et al. 2012; Frigerio et al. 2018; Pocock et al. 2017; Wals et al. 2014). There have been numerous efforts to describe the breadth of citizen science research, understand how and why projects are undertaken, and their scientific value (Kleinke et al. 2018; Kobori et al. 2016; Parsons et al. 2018; Pocock et al. 2017; Silvertown 2009). Approaches are diverse and range from long-term ecological monitoring and nation-wide species observations, to recording behaviours or sources of mortality (e.g. Frigerio et al. 2018; Gardiner et al. 2012; Vercayie and Herremans 2015). Projects may differ in their emphasis on educational goals, scientific outputs, engagement and awareness raising, behaviour or environmental change, participant roles and level of participation (Bonney et al. 2009; Dickinson et al. 2010; Wiggins and Crowston 2011). Despite the wide variety of approaches, contexts and goals, a cornerstone of all citizen science projects is their capacity to generate robust scientific data. Scientific outputs must remain a central goal in order for a project to be considered a citizen science, as opposed to a science education, conservation volunteering, or awareness raising exercise.

Involving schools in citizen science projects represents an opportunity to engage younger audiences in environmental research (Kobori et al. 2016). The benefits of engaging school students as citizen scientists include improved scientific literacy, environmental awareness, leadership skills, and the potential to inspire new generations of environmentally aware and active citizens (Ballard et al. 2017; Pitt and Schultz 2018; Wals et al. 2014). Alongside the scientific outputs, school-based citizen science projects should also provide educational 
benefits to the student participants (Zoellick et al. 2012). However, striking the right balance between scientific and educational outcomes may be difficult (Zoellick et al. 2012). Trade-offs occur when the needs of scientists and the needs of students are at odds, and the project may be pulled to suit one goal at the expense of the other.

School-based citizen science projects in the field of wildlife research can engage younger audiences in environmental science by tapping into children's natural fascination with animals. However, wild animals can be difficult to work with and scientists may be cautious about bringing these challenges into a school setting. For example, some study species and associated survey methods may be more appealing or feasible than others, and the types of projects best suited to younger students are likely to differ to those for adults. Concern about the degree to which the data will be reliable and publishable is another perceived barrier to the involvement of school students in citizen science, particularly for younger age-groups (Burgess et al. 2017; Pitt and Schultz 2018; Trautmann et al. 2012). While students of all ages are often excited to work with wildlife, they may quickly lose interest when faced with the reality that some methods of data collection are monotonous, uneventful or indirect, which may compromise the integrity of the research findings. This concern is particularly relevant to long-term wildlife monitoring programs, complicated experimental designs (e.g. before-after, control-impact designs), methods that require accurate and repeated timing, or situations where the study species is difficult to observe or detect. Operating within the constraints of a school environment also presents operational and logistical challenges that may compromise data collection. For instance, field observations that are required outside of school hours, or outside of the school grounds require an extra level of organisation. Finally, the scientists themselves may have limited training in engaging and communicating with school-aged children to deliver educational outcomes that align with curriculum requirements (McKeown 2003).

Understanding the possible challenges and benefits of embarking on a school-based citizen science project will assist researchers to make an informed decision on whether to such a project is appropriate for their research question, and to design projects that generate scientific data while providing an engaging and educational experience to student scientists. Here, we explore the potential opportunities and challenges of school-based citizen science in the field of wildlife research. We ask: 1) Can school-aged children contribute reliable data to a citizen science project in wildlife research? 2) What factors influence the success of schools-based citizen science in wildlife research? To address these questions, we first present the results of, and discuss our experience from, a citizen science research project conducted in six schools across Australia (Part 1). We then review the literature to build a database of school-based citizen science projects involving wildlife research (Part 2). Finally, we synthesise this information into a set of five lessons to guide researchers who are considering school-based citizen science.

\section{PART 1: Field case study. An urban bird feeding experiment through the Scientists in Schools Program Aims and context}

We established a school-based citizen science project as part of the Commonwealth Scientific and Industrial Research Organisation (CSIRO) Scientists in Schools Program, in collaboration with the Ecological Society of Australia and the New South Wales Office of Environment and Heritage. The goal was to engage primary 
school students in ecological research by pairing six early-career ecologists (the authors) with schools across Australia and conduct a research project in which the students collected the data as citizen scientists.

Our research project investigated how supplementary feeding affects wild birds in urban areas, as measured by the presence, abundance, and richness of species before and after adding seed to feeding stations. Bird-feeding is a common activity in urban environments and a topical conservation issue (Galbraith et al. 2015; Jones 2018) and thus presented a good opportunity to teach students about urban biodiversity, ecology and wildlife management. Supplementary feeding may affect the composition of bird communities by favouring larger, aggressive birds to the detriment of other species, or by attracting new species to the area (Galbraith et al. 2015; Reynolds et al. 2017). The research question posed to the students: how does adding bird seed change the number and type of birds observed at school? We expected to see an increase in observations of granivorous bird species after seed was added.

Methods

We used a before-after experiment to assess how supplementary feeding influenced bird species richness and abundance. During the 'before' phase, 2-4 feeding stations (20 cm dishes suspended by wire chain) were hung in trees at each school but no food was added. During the 'after' phase, students added a wild bird seed mix to the feeding stations each morning. Six schools participated in the project: Wattle Park Primary School, Burwood, Victoria; Montmorency South Primary School, Montmorency, Victoria; Princes Hill Primary, Parkville, Victoria; Coburg West Primary School, Victoria; Lake Clarendon State School, Lake Clarendon, Queensland; and Northside Montessori School, Sydney, New South Wales (Figure 1). This involved approximately 185 students (aged 9-12) in the data collection. Researchers guided the project during 3-5 visits throughout the term, however the students collected the data independently following the initial training without the presence of the researchers.

The students conducted 10-minute bird surveys at feedings stations for three weeks before and three weeks after seed was added (allowing a one week 'habituation' period in between) during a single 10 -week school term $\left(1^{\text {st }}\right.$ May $-22^{\text {nd }}$ July 2017). Two or three students collected data independently at each feeder during each survey. Students were encouraged to conduct surveys each morning, however the frequency varied. For example, the degree to which the project was allocated class time differed among schools and as a result some students had to adjust the timing of surveys to fit with their other school commitments. The total number of survey days at each school ranged from 17 to 30. The number of survey days before and after seed was added ranged from 9 to 19 days before, and 6 to 15 days after. We collated the data collected by the students, adjusting counts to account

We took several steps to help the students engage with the project and collect accurate data throughout the course of the study. Prior to the data collection, each researcher visited their assigned school to meet the students and introduce the project. Researchers discussed the arguments for and against bird feeding, the 
through why measurements should be taken before and after seed was added, and devise hypotheses about which types of birds would likely respond to the feeders (e.g. birds that eat seeds). We toured the school grounds as a group, and the students were asked to identify the best locations to place the bird feeders based on their understanding of the aims of the study. During this tour, we further discussed the before-after approach and the students' expectations of what changes they might observe, when, and why. During the first school visits, we also trained the students in basic bird identification and survey methods, including a 'practice run' around the school grounds using a draft datasheet. We observed how the students counted and identified species, used group exercises to explore how counts were conducted and compared, and explained how to record bird size, colour and behaviour to help identify species from field guides back in the classroom. This initial phase helped us identify where the datasheet needed to be streamlined or clarified to allow for easy and accurate identifications and counts before the official data collection commenced. For example, students had difficulty distinguishing between sulphur-crested cockatoos and corellas, however as the difference between these species was not critical to our research question, we provided the simpler category of 'white cockatoos' on the data sheet (Supplementary Material). This allowed us to maintain a focus on the aspects of the data collection that were important to the research question, and discard those that led to unnecessary confusion. We developed an easy-to-use data sheet with photos and checkboxes for each species likely to be observed in the local area (Supporting Information). A five-metre 'bird watch zone' was marked out around each feeding station using either temporary spray paint on the ground or by assigning landmarks which guided students to only count birds that were close to the feeding station.

\section{Reflection on scientific outcomes}

A total of 2,803 observations of 25 species were recorded during 328 survey days at the 16 feeders. The most common species observed were the Rainbow Lorikeet Trichoglossus moluccanus ( $\mathrm{n}=416$ observations), Crested Pigeon Ocyphaps lophotes (380), Noisy Miner Manorina melanocephala (349), introduced House Sparrow Passer domesticus (286), Galah Eolophus roseicapilla (282), Raven Corvus spp. (114) and introduced Spotted Dove Spilopelia chinensis (108). Of the remaining species, 1-97 observations were recorded. A further 90 and 192 observations were assigned to "Other" and "Unknown bird", respectively. Mean species richness across all surveys and feeders ranged from 0.89 species at Wattle Park to 4.85 at Montmorency South. Visual inspection of the data (Figure 2) reveals mixed responses of bird abundance and species richness to the provision of food and high variability within some schools. However, we had some concerns about the ecological nature of these responses due to the limitations of the study design and data collection, and do not consider the data appropriate for addressing our research question.

A key challenge in this project was maintaining the students' interest in the experimental component of the study, which eompromised the reliability of the before-after comparison and our confidence in the results. While the students understood the goal of a before-after comparison, many were less interested when there was little or no bird activity, particularly during the 'before' phase. During site visits, we noticed that some students were enthusiastically recording all the birds they saw, regardless of whether they were within the 'bird watch zone'. At four schools, we responded to this behaviour by amending the methods to also include 'around school' surveys, where birds not within the 'bird watch zone' could be recorded on a separate sheet and thus not affect 
the experiment. This allowed students to develop their bird watching and identification skills, even when activity at the feeders was low. However, as we were only able to introduce this approach mid-way through the study and at only four out of the six schools, we are not confident that the before-after bird observations were collected as intended; birds who were unlikely to have ever encountered the feeding stations were included in the total counts. Another concern was the sparse nature of the records. While the study was intended to consist of daily, morning surveys over a seven-week period, most schools had fewer observation days than this. This was particularly the case when the project was not embedded within designated class time and other school requirements took precedence (e.g. roll call, sports days). In hindsight, we believe our study design was not appropriate for the student's age and the low frequency of investigator visits.

\section{Reflection on educational outcomes for students}

Notwithstanding the above, the students were very engaged in the project and capable of independently conducting the bird surveys. We did not formally assess the student's engagement, enjoyment or learning outcomes as part of our study, and acknowledge that this would be a useful addition to future school-based citizen science projects. Still, we noticed that very few students could identify bird species during the first school visit and by the end of the project students could confidently identify common bird species by sight, call or flight pattern. When birds could not be identified at first sight, the students developed the skills to note down the defining features (such as size, call, behaviour and shape) and drew the birds so that we could search field guides and identify them afterwards. We also found that it was important to maintain a flexible approach that allowed us to respond to the changing needs of the students and school environment. For example, while we had a base lesson plan for the project, each researcher tailored this based on the age, size and interests of their classes, and the time available at each school. Some students created species 'fact sheets', bird watching clubs, collected feathers, or completed other side projects to complement the research.

\section{PART 2: Review of literature on wildlife research projects using school-based citizen science}

\section{Search methods and criteria}

We searched the scientific literature for articles describing school-based citizen science projects involving wildlife research to identify the degree to which such projects have led to published science. We defined 'school-based citizen science' as a project in which students at primary or secondary schools were primarily or solely responsible for collecting data (as opposed to a broader citizen science program that may involve schoolaged children). We acknowledge that many such programs will not be described within the scientific literature, but we use peer-reviewed publications as a simple indicator of the degree to which school-scientist partnerships generate scientific outcomes that are accessible to the broader research and management communities (Burgess et al. 2017). We defined 'wildlife research' as any research project in which vertebrate or invertebrate fauna were the response organism, with a specific focus on ecological and conservation research (i.e. not laboratory or domestic animals).

We searched Scopus using the terms "citizen science" OR "citizen scientist" AND "ecol*" OR "conserv*" $\left(10^{\text {th }}\right.$ July 2018), which yielded 950 documents. Further refining this search using the terms "children" or "student" returned 74 and 77 documents, respectively. We screened the title and abstract of each paper to create a shortlist 
of articles in which school students conducted research and fauna were the response measure. We inspected the literature cited within these documents to identify additional articles of relevance. Articles were excluded from consideration if the data was not collected by school students, the measured response was something other than fauna (i.e. flora, abiotic conditions), the work was presented in a language other than English, or the full text was not accessible. We excluded several projects that were peripherally related to the topic but were out of the scope of our main investigation. These included projects that were school-based but not focused on wildlife, such as research into the fields of forestry and urban trees (e.g. Galloway et al. 2006), marine debris (e.g. Hidalgo-Ruz and Thiel 2013), or water and air quality (e.g. Giles and Parson 2001; Nali and Lorenzini 2007). Several other projects included young people and students among the participants, but were not focused on citizen science in a school environment (e.g. Gardiner et al. 2012; Parsons et al. 2018), or presented classroom modules for broader citizen science projects of which the results were not yet published (e.g. Ezran et al. 2017; Lucky et al. 2014; Wells 2010).

\section{Overview of projects}

We identified 18 school-based citizen science projects from 15 documents in which students from primary or secondary schools collected data that contributed to research on the ecology or conservation of wildlife (Table 1). These occurred as standalone papers or were presented as case-studies in reviews or editorial pieces.

\section{Taxa studied and research activities}

The school-based studies described research on benthic intertidal communities, lizards, large ungulates and carnivores, migratory birds, small mammals, macroinvertebrates, butterflies, bees and other pollinating insects (Table 1). Observations were not limited to within the school grounds, with several research projects using field trips, school-bus commutes, or the students' backyards as sources of data. The diversity of methods allowed students to conduct research on species that might otherwise be difficult or dangerous to observe. For example, Weckel et al. (2010) investigated the distribution of human-coyote interactions in suburban New York by asking school students to interview their parents, and Galloway et al. (2011) had students count large mammals observed during their morning bus commute.

Most studies engaged students in simple observational methods to report animal behaviour, human-wildlife relationships, or exploring relationships between environmental features and species occurrence. Only two studies included more complex manipulative experiments, one investigating the influence of colour signals on foraging in bumblebees (Blackawton et al. 2011), and the other investigating the influence of substrate characteristics on maternal nest site choice in lizards (Reedy et al. 2012). In studies of invertebrates, such as garden insects or intertidal communities, students had direct contact with wildlife and conducted the trapping, handling and observations (e.g. Cox et al. 2012; Osborn et al. 2005; Saunders et al. 2018). Students were rarely in direct contact with vertebrate wildlife, and instead observed the behaviours of individuals that had been previously marked by researchers, recorded tracks and other signs of wildlife, or interviewed local residents about their perspectives on wildlife (e.g Frigerio et al. 2018; Weckel et al. 2010). Only two articles described students handling vertebrate wildlife, in which students were involved in trapping, handling and processing 
lizards (Matthews et al. 2014; Reedy et al. 2012). One study included DNA barcoding, in which the students collected the samples and sent them away to laboratory for analysis (Henter et al. 2016).

\section{Models of scientist-student interaction}

The degree of contact and engagement between scientists and students varied widely. Examples ranged from students filling out and returning simple proforma and having little contact with the scientist (Henter et al. 2016; Weckel et al. 2010), to supervised field-trips where the scientists were present during the data collection (Freiwald et al. 2018), to student-led research where students wrote the final published paper (Blackawton et al. 2011). Lower input from scientists was often associated with programs that provided intensive teacher training and curriculum resources, or those had simpler methods that could be easily completed with minimal supervision. The more intensive school-scientist relationships usually involved internships or were supported by dedicated citizen science programs (e.g. Matthews et al. 2014; Pitt and Schultz 2018) Several studies codeveloped the research questions with the school or involved the students in the data analysis and writing of the paper (Blackawton et al. 2011; Saunders et al. 2018). Other programs included teacher training and formal curriculum support to foster long-term partnerships (Cox et al. 2012; Freiwald et al. 2018; Frigerio et al. 2018) or published 'teaching notes' to help guide implementation across multiple schools (Matthews et al. 2014). Providing this additional support to teachers helped to improve the longevity of the project and quality of data.

Approaches to maintaining scientific outcomes

The school-based citizen science projects we reviewed clearly demonstrated the scientific value of research conducted by student citizen scientists. Data generated through these projects resulted in an improved understanding of species ecology and behaviour (Blackawton et al. 2011; Reedy et al. 2012), contributions to large-scale biodiversity databases (Henter et al. 2016; Matthews et al. 2014), and were used to inform wildlife management (Pitt and Schultz 2018; Zoellick et al. 2012). For example, students citizen scientists in the School Malaise Trap Project helped add the DNA barcodes of more than 1000 new species to the Barcode of Life Database (Henter et al. 2016). Several researchers explicitly note that the quality of data collected by students was comparable to that collected by professional scientists (Frigerio et al. 2018; Osborn et al. 2005; Pitt and Schultz 2018).

Common approaches to maintaining data quality included age-appropriate training; protocols with well-defined, relevant parameters; regular visits from the partner scientist; recording inter-observer reliability; and verifying data using experts (Cox et al. 2012; Freiwald et al. 2018; Frigerio et al. 2018; Le Féon et al. 2016). Crossvalidation methods were an important approach to ensuring confidence in the data collected by student citizen scientists. Approaches to data validation were described for 11 projects, and included the use of multiple observers and replicate counts (Cox et al. 2012; Freiwald et al. 2018; Osborn et al. 2005), comparison to data collected by scientists (Osborn et al. 2005), or verification of data points by teachers or scientists (Frigerio et al. 2018; Pitt and Schultz 2018). Several studies introduced frameworks for obtaining high-quality data through school-based citizen science, highlighting the importance of exciting students and allowing buy-in, training, simplified and tailored protocols, cross-validation methods, and validity assessment (Cox et al. 2012; Osborn et al. 2005; Zoellick et al. 2012). 
317 A key source of uncertainty in wildlife research was the capacity of students to distinguish between similar 318 looking species, identify rare species, or record nuanced behavioural responses. Some researchers tackled this 319 problem by simplifying the list of species under observation. For example, students were directed to record observations from a prescribed list that included only those species which could be reliably identified, excluding species that were uncommon, or grouping together those that were difficult to distinguish (Freiwald et al. 2018; Osborn et al. 2005). Other researchers adopted a community-level rather than species-level approach, grouping insects into simpler categories (e.g. flies, bees and wasps) based on features that were simpler to accurately identify (Saunders et al. 2018). Simplifying the data collection in this way was an attempt minimise errors by collecting only the information that is critical to answering the research question rather than a 'laundry list' of observations just in case they are useful. However, oversimplification may limit the capacity of conservation studies that need to record rare species, studies where species of similar appearance have different ecological responses, or studies of subtle behaviours (Freiwald et al. 2018). Alternative approaches were to train students in the subtleties of each species through repeated exposure (Cox et al. 2012; Matthews et al. 2014) or have more complicated identifications completed by scientists (Le Féon et al. 2016). For example, in Matthews et al. (2014), researchers were concerned that students would not be able to distinguish between three similar-looking species of skink. To combat this, the researchers first used a pet bearded dragon to familiarise students with the general anatomical features of lizards on a larger scale. The researchers then brought native skinks into the classroom, allowing the students to observe and compare the distinguishing features of each species first-hand and refine their identification skills, even if the subsequent field surveys turned out to be unsuccessful.

\section{Constraints and opportunities for scientists}

There were several benefits to scientists engaging in school-based citizen science programs. For example, such programs provide the opportunity to access biodiversity in urban areas that would typically be unavailable or difficult to access, such as school grounds and urban backyards (Frigerio et al. 2018; Saunders et al. 2018; Weckel et al. 2010). Perhaps most promising is the opportunity for school-based citizen science projects to increase the temporal or spatial scales of data collection, with projects continuing over many years or including multiple schools. For example, the monitoring of species in rocky intertidal habitats in California's Monterey Bay National Marine Sanctuary (USA) will form part of a long-term monitoring program generating data for the National Oceanic and Atmospheric Administration, with new classes visiting the sites using the same protocols each year. Similarly, the Acadia Learning Project has involved eleven schools and thousands of students over large spatial scales to identify landscape-scale patterns of mercury levels in stream macroinvertebrates (Zoellick et al. 2012).

However, the school environment also placed constraints on the type of species and study that can be conducted. The rigidity of the school environment or curriculum can be a barrier to obtaining reliable data (Frigerio et al. 2018; Saunders et al. 2018). For example, surveys to observe social interactions of northern bald ibis (Geronticus eremita) were best conducted in the early morning, however the class time allocated for this activity occurred in the late-morning, meaning the data collected by the students were not informative (Frigerio et al. 2018). Researchers noted a trade-off between making it easy for school students to be involved and maintaining 
the integrity of the data, and, thus, the capacity of the program to achieve the scientific outcomes as intended (Freiwald et al. 2018; Le Féon et al. 2016; Osborn et al. 2005). For example, Osborn et al. (2005) provided flexible lesson plans, enabling teachers to tailor their involvement in the monitoring of benthic intertidal communities based on the needs of the class. However, they cautioned that too much flexibility may compromise the consistency of the monitoring, with some sites surveyed more frequently than others due to ease of access. Similarly, simplifying the methods to enhance student participation can lead to the loss of valuable information and limit the types of research questions that can be explored (Freiwald et al. 2018; Le Féon et al. 2016; Osborn et al. 2005). Finally, access to the target species may also limit the capacity of schoolbased citizen science in wildlife research. When the target species can only be found outside of the school grounds, field trips and excursions can be logistically difficult and costly (Cox et al. 2012).

\section{Engagement and educational outcomes}

Six of the 18 examples of school-based citizen science projects described an evaluation of student or teacher experience of the program (Frigerio et al. 2018; Henter et al. 2016; Pitt and Schultz 2018; Zoellick et al. 2012). Educational and engagement outcomes were most commonly assessed through before-after surveys of students or teachers, determining the degree to which students learned (Zoellick et al. 2012), the aspects of the science that they found most interesting (Frigerio et al. 2018), or the teachers' perspectives of how the program could be improved in future iterations (Cox et al. 2012). For example, Pitt and Schultz (2018) found that students showed a greater interest in careers in natural resource management after participating in research projects with the US Forest Service, while Frigerio et al. (2018) found that students were least interested in data entry and most excited by tasks involving specialised equipment. Researchers also noted the project's alignment with the mandated curriculum requirements, either by embedding the project within the curriculum (Cox et al. 2012; Freiwald et al. 2018; Henter et al. 2016; Pitt and Schultz 2018) or informal feedback from teachers after the work was completed (Saunders et al. 2018).

While formal assessments were rarely described, anecdotal examples of student engagement were common (Cox et al. 2012; Osborn et al. 2005; Saunders et al. 2018). There were several examples of students taking ownership of the projects and independently pursuing their own research questions (Osborn et al. 2005; Zoellick et al. 2012). Scientists often took additional steps to enhance engagement and learning for students including art and drawing assignments, interactive presentations and quiz games, field excursions, and emphasising their role as citizen scientists (Frigerio et al. 2018; Osborn et al. 2005). In Blackawton et al.(2011), the students were engaged throughout the entire process, not only devising the research questions and carrying out the data collection, but also writing the published paper, complete with hand-drawn figures.

\section{SYNTHESIS}

Overall, our review suggests that school-based citizen science projects that result in peer-reviewed scientific publications are relatively rare, but the few examples we found illustrate the potential for student citizen scientists to generate robust data and indicate that many of the perceived obstacles can be overcome through careful project design. The scarcity of school-based citizen science projects may reflect the infrequency with which such projects take place, the degree to which such projects generate publishable results, or the frequency 
with which they intend to generate data for peer-reviewed publications. Certainly, both our case study and the literature review highlight the difficulties in generating robust data from school-based citizen science projects and there are undoubtedly many unpublished examples of school-based citizen science projects that failed to generate the quality of data expected. These difficulties may lead scientists to avoid engaging with schools, or to do so for educational rather than scientific reasons. However, our research suggests that the main reasons school-based citizen sciences fail is because the science was not tailored to engage students to collect quality data, or the educational and engagement aspects were over-emphasised at the expense of data integrity. Through careful consideration, these challenges can be overcome, enabling student citizen scientists to generate robust scientific data. To that end, we synthesise five key lessons from our experience and the broader literature to help researchers maximise both the scientific and educational outcomes of school-based citizen science projects. These are of particular relevance to wildlife research but will also be valuable to school-based citizen science projects more broadly.

1. Most species can be suitable subjects with creative methods: While there are some practical and ethical considerations to bear in mind, most wildlife taxa can be appropriate study subjects for schoolbased citizen science. The methods should be tailored to ensure that they are appropriate to the age of the students, allowing them to engage with the species in a way that is safe and interesting, yet still contributing to reliable data. The use of virtual-based activities, camera-traps, and non-invasive sampling methods could further expand the range of taxa under investigation. However, the misidentification of rare species has important implications of many conservation studies, and therefore should be carefully managed through training if this is a key goal.

2. Robust data can be collected if appropriate measures are used: Age-appropriate training, regular validation, and simplified protocols all serve to enable robust data collection, allowing the data collected by student citizen scientists to be comparable with other studies. Striking the right balance between independent data collection and scientist oversight is critical to ensuring that the data collected meet the scientific goals of the project, and that the students benefit from meaningful engagement with a working scientist (Gardiner et al. 2012; Le Féon et al. 2016; Zoellick et al. 2012). When deciding how much time to invest, it is worth remembering that the interactions with the working scientists are often the student's most popular and important aspects of the experience (Henter et al. 2016; Trautmann et al. 2012; Zoellick et al. 2012).

3. Engagement and educational outcomes should be explicitly measured: Educational outcomes are an important component of school-based citizen science projects and as such the ability of the project to deliver these outcomes should be formally assessed rather than assumed. Simple before-after surveys that assess learning, interest, and behaviour change can be used to improve the design and delivery of programs by determining which aspects of the research were enjoyable, well-understood, or easy to complete within the school routine (e.g. Frigerio et al. 2018; Pitt and Schultz 2018). However, it should be noted that when the students become the data, rather than the data collectors, appropriate ethics approvals and processes should be considered, and we recommend consulting or collaborating with social scientists or education researchers where possible.

4. Establish curriculum support and formal partnerships: Formal partnerships can ensure that both the schools and scientists have access to the infrastructure and administrative support required to develop 
meaningful and sustainable projects. This can be achieved by working with organisations that have existing science education and outreach programs (Ballard et al. 2017; Zoellick et al. 2012) or establishing initiatives within the university to support scientists in schools (e.g. Henter et al. 2016; Matthews et al. 2014). Some training may be required to assist teachers to lead the students through the scientific aspects of the project, or to help scientists improve their teaching and communication skills (Frigerio et al. 2018; McKeown 2003). Working with schools to embed the research project within the curriculum can also help to ensure that the data collection is given adequate time and suits the survey methods for the target species, and that the project is designed to meet educational outcomes (McKeown 2003; Trautmann et al. 2012; Zoellick et al. 2012).

5. Keeping students interested is critical to success: If the student citizen scientists find their role in the research tedious, confusing or too difficult, they may disengage from the project and be unlikely to generate robust data. Allowing the students to be part of the process by contributing ideas and research questions helps to improve learning outcomes, and fosters a sense of ownership and investment in the project (Trautmann et al. 2012; Zoellick et al. 2012). Researchers should make an effort to engage students by ensuring data is fed back into the classroom and providing students the opportunity to analyse and present the data themselves (e.g. Blackawton et al. 2011; Henter et al. 2016). Consider including simple methods that maintain interest and engagement, such as collection of feathers and shed exoskeletons, or observations of tracks and scats.

While our case study did not deliver the scientific outcomes intended, careful review of the process in light of the lessons above suggests how we could design a more successful approach in future. Changes would include: increasing the level of scientist-supervision to match the complexity of the experimental; formally comparing student engagement and learning outcomes before and after the project; more clearly communicating the research findings back to the schools and highlighting each school's contribution in the scope of the broader study (e.g. "What did the other schools find out?"). We would also work to establish a longer-term relationship with the schools to co-develop the project, gaining a better understanding of the research methods and scientific outcomes that would be possible, and the educational outcomes that would best match the current curriculum requirements. Such approaches could help achieve more robust scientific results, as well as improved educational outcomes for students.

Bringing citizen-science programs into schools has the capacity to deliver research, education and environmental outcomes, and taps into student's natural fascination with wildlife. School-based citizen science can also benefit researchers by providing the capacity to conduct long-term studies (e.g. working with multiple classes over multiple years, Freiwald et al. 2018), coordinated distributed experiments (e.g. implementing the same research protocol across multiple schools, Henter et al. 2016), and access to sites that are rarely studied yet may have important biodiversity value and conservation opportunities (e.g. private land or urban environments, Frigerio et al. 2018; Saunders et al. 2018). However, it is important that researchers maintain clear goals and realistic expectations - not all projects, or all species, will be suitable - and we recommend starting with a pilot program so that the approach and expectations can be revised early on. The database of studies provided here serve as an excellent source of reference for researchers embarking on school-based citizen science projects, and 

2012). Ultimately, engaging school students in wildlife research will be a balancing act between scientific and educational outcomes.

\section{Tables and Figures}

Table 1. Results of literature search for school-based citizen science projects involving wildlife.

\begin{tabular}{|c|c|c|c|c|}
\hline Project & Aim of wildlife research & Student level & Country & Reference \\
\hline $\begin{array}{l}\text { The year of the greylag } \\
\text { geese }\end{array}$ & $\begin{array}{l}\text { Long-term research into social behaviour of greylag } \\
\text { geese at the Konrad Lorenz Research Station }\end{array}$ & $\begin{array}{l}\text { Primary and } \\
\text { secondary school }\end{array}$ & Austria & $\begin{array}{l}\text { In Frigerio et al. } \\
\text { (2018) }\end{array}$ \\
\hline Nature in your backyard & $\begin{array}{l}\text { Investigating the role of gardens in enhancing } \\
\text { backyard biodiversity, including surveys for } \\
\text { hedgehogs, birds and pollinating insects. }\end{array}$ & $\begin{array}{l}\text { Primary and } \\
\text { secondary school }\end{array}$ & Austria & $\begin{array}{l}\text { In Frigerio et al. } \\
\text { (2018) }\end{array}$ \\
\hline $\begin{array}{l}\text { Social alliance in bald } \\
\text { ibis }\end{array}$ & $\begin{array}{l}\text { Movement ecology, social behaviour, stress and } \\
\text { parasite load of bald ibis. }\end{array}$ & $\begin{array}{l}\text { Primary and } \\
\text { secondary school }\end{array}$ & Austria & $\begin{array}{l}\text { In Frigerio et al. } \\
(2018)\end{array}$ \\
\hline $\begin{array}{l}\text { Our Project in Hawaii's } \\
\text { Intertidal (OPIHI) }\end{array}$ & $\begin{array}{l}\text { Describe the distribution and abundance of } \\
\text { introduced and native species in benthic rocky } \\
\text { intertidal communities }\end{array}$ & Secondary school & Hawaii & Cox et al. (2012) \\
\hline $\begin{array}{l}\text { School Malaise trap } \\
\text { program }\end{array}$ & $\begin{array}{l}\text { Explore insect diversity around school yard using } \\
\text { Malaise traps and DNA barcoding }\end{array}$ & $\begin{array}{l}\text { Primary and } \\
\text { secondary school }\end{array}$ & Canada & $\begin{array}{l}\text { Henter et al. (2016); } \\
\text { Steinke } \text { et al. (2017) }\end{array}$ \\
\hline $\begin{array}{l}\text { Long-term Monitoring } \\
\text { Program and } \\
\text { Experimental Training } \\
\text { for Students } \\
\text { (LiMPETS) }\end{array}$ & $\begin{array}{l}\text { Monitoring rocky shore and sandy beach intertidal } \\
\text { habitats, measuring presence-absence and number } \\
\text { of species such as sea stars, limpets and crabs } \\
\text { within National Marine Sanctuaries. }\end{array}$ & $\begin{array}{l}\text { Primary and } \\
\text { secondary school }\end{array}$ & USA & $\begin{array}{l}\text { Freiwald et al. } \\
\text { (2018); Ballard et } \\
\text { al. (2017) }\end{array}$ \\
\hline $\begin{array}{l}\text { Monterey Bay National } \\
\text { Marine Sanctuary }\end{array}$ & $\begin{array}{l}\text { Monitoring long-term changes in rocky intertidal } \\
\text { communities }\end{array}$ & Secondary & USA & $\begin{array}{l}\text { Osborn et al. } \\
\text { (2005) }\end{array}$ \\
\hline $\begin{array}{l}\text { Herpetological } \\
\text { Research Experience }\end{array}$ & $\begin{array}{l}\text { Mark-recapture study of lizards to investigate } \\
\text { species diversity and distribution. }\end{array}$ & Secondary school & USA & $\begin{array}{l}\text { Matthews et al. } \\
\text { (2014) }\end{array}$ \\
\hline $\begin{array}{l}\text { Alaska Natural Science } \\
\text { Course }\end{array}$ & $\begin{array}{l}\text { A range of longitudinal research projects, including } \\
\text { collecting data on wildlife abundance, density and } \\
\text { distribution. Students develop research projects } \\
\text { over semesters in collaboration with the US Forest } \\
\text { Service, }\end{array}$ & Secondary school & USA & Pitt et al. (2018) \\
\hline $\begin{array}{l}\text { Montana Youth Forest } \\
\text { Monitoring Program }\end{array}$ & $\begin{array}{l}\text { Student internships with the US Forest Service to } \\
\text { learn about forest management and help conduct a } \\
\text { variety of wildlife monitoring projects. }\end{array}$ & Secondary school & USA & Pitt et al. (2018) \\
\hline $\begin{array}{l}\text { Delta Science } \\
\text { Apprenticeship } \\
\text { (Colorado) }\end{array}$ & $\begin{array}{l}\text { Student apprenticeships with the US Forest Service, } \\
\text { focusing on learning habitat restoration and wildlife } \\
\text { monitoring skills. }\end{array}$ & Secondary school & USA & Pitt et al. (2018) \\
\hline
\end{tabular}




$\begin{array}{lllll}\text { Human coyote interface } & \begin{array}{l}\text { Mapping human-coyote interaction in urban } \\ \text { environment through students interviewing their } \\ \text { parents. }\end{array} & \begin{array}{l}\text { Primary and } \\ \text { secondary school }\end{array} & \text { USA } & \text { Weckel } \text { et al. (2010) } \\ & \begin{array}{l}\text { Long-term sampling and mapping of mercury } \\ \text { levels in macroinvertebrates. }\end{array} & \text { Secondary school } & \text { USA } & \text { Zoellick } \text { et al. } \\ \text { Acadia Learning Project } & \text { (2012) }\end{array}$
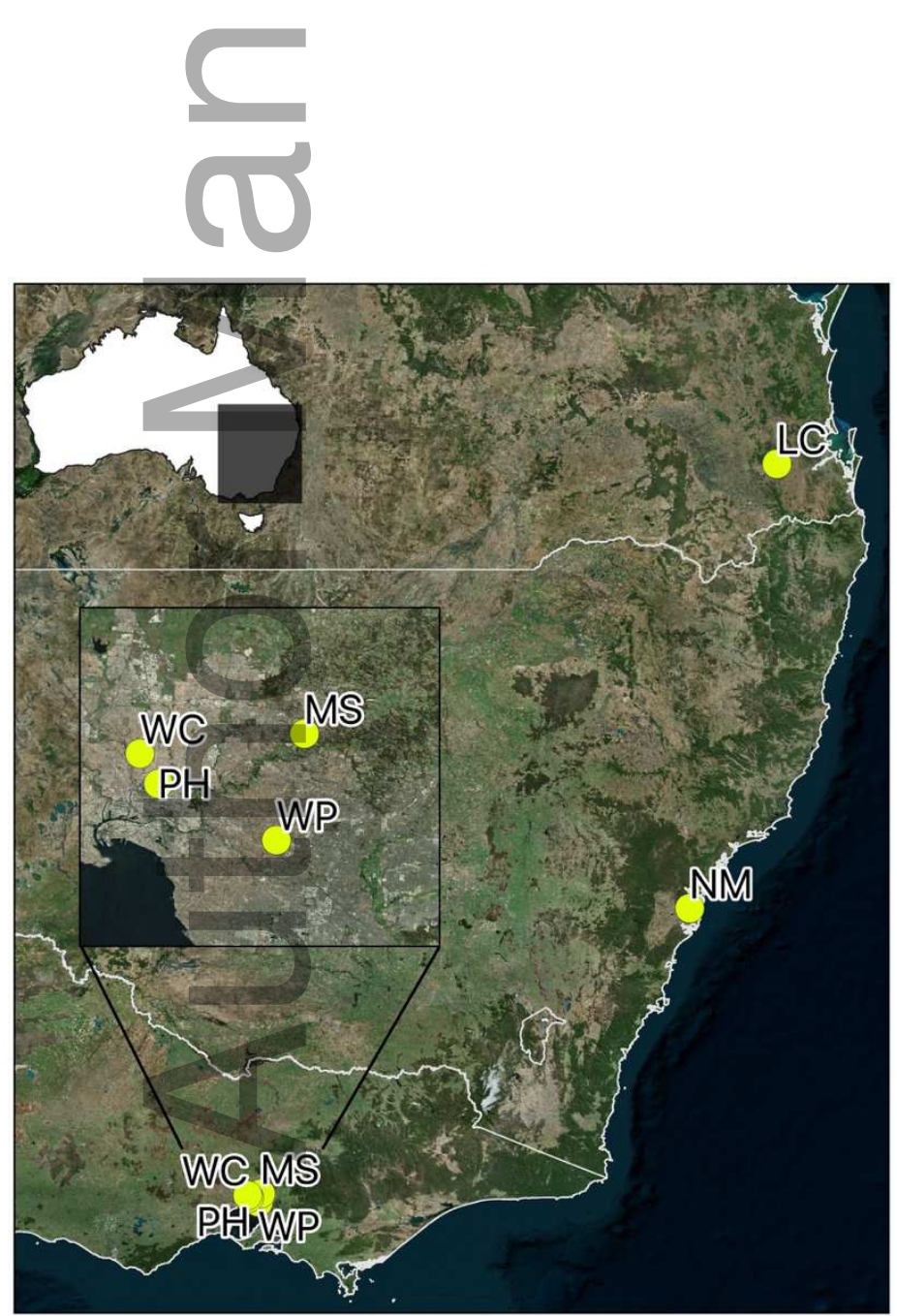
Figure 1. Location of the six schools where bird data was collected. LC, Lake Clarendon State School; MS, Montmorency South Primary School; NM, Northside Montessori School; PH, Princes Hill Primary; WC, Coburg West Primary School; WP, Wattle Park Primary School.

Total abundance

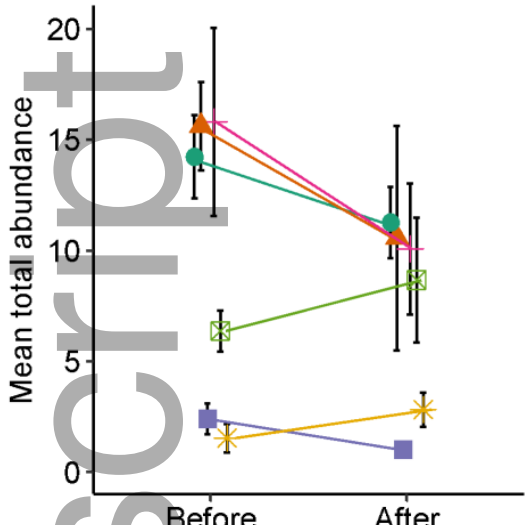

Species richness

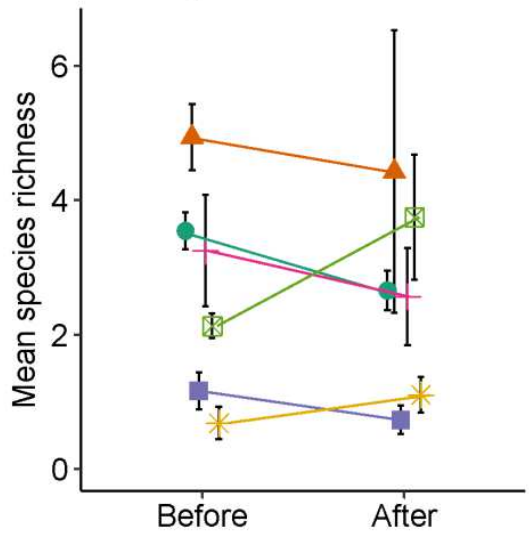

School

- LC

- MS

- $\mathrm{NM}$

$+\mathrm{PH}$

$\otimes W C$

* WP
491

492

493

494

495

496

Figure 2. Mean $( \pm$ SE) bird abundance and species richness before and after seed was added to feeders. The values for each school are means across all feeders and surveys within each of the before and after periods. LC, Lake Clarendon State School; MS, Montmorency South Primary School; NM, Northside Montessori School; PH, Princes Hill Primary; WC, Coburg West Primary School; WP, Wattle Park Primary School.

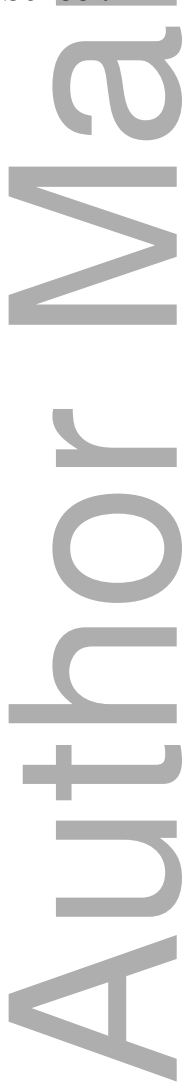


Ballard H. L., Dixon C. G. \& Harris E. M. (2017) Youth-focused citizen science: Examining the role of environmental science learning and agency for conservation. Biol. Conserv. 208, 65-75.

Blackawton P., Airzee S., Allen A., Baker S., Berrow A., Blair C., Churchill M., Coles J., Cumming R.-J. \&

Fraquelli L. (2011) Blackawton bees. Biology Letters 7, 168-72.

Bonney R., Cooper C. B., Dickinson J., Kelling S., Phillips T., Rosenberg K. V. \& Shirk J. (2009) Citizen science: A developing tool for expanding science knowledge and scientific literacy. Bioscience 59, 977 - 84.

Burgess H., DeBey L., Froehlich H., Schmidt N., Theobald E., Ettinger A., HilleRisLambers J., Tewksbury J. \& Parrish J. (2017) The science of citizen science: Exploring barriers to use as a primary research tool. Biol.

Conserv. 208, 113-20.

Cox T., Philippoff J., Baumgartner E. \& Smith C. (2012) Expert variability provides perspective on the strengths and weaknesses of citizen-driven intertidal monitoring program. Ecol. Appl. 22, 1201-12.

Dickinson J. L., Shirk J., Bonter D., Bonney R., Crain R. L., Martin J., Phillips T. \& Purcell K. (2012) The current state of citizen science as a tool for ecological research and public engagement. Frontiers in Ecology and the Environment 10, 291-7.

Dickinson J. L., Zuckerberg B. \& Bonter D. N. (2010) Citizen science as an ecological research tool: challenges and benefits. Annual Review of Ecology \& Systematics 41, 149 - 72.

Ezran C., Karanewsky C. J., Pendleton J. L., Sholtz A., Krasnow M. R., Willick J., Razafindrakoto A., Zohdy S., Albertelli M. A. \& Krasnow M. A. (2017) The mouse lemur, a genetic model organism for primate biology, behavior, and health. Genetics 206, 651-64.

Freiwald J., Meyer R., Caselle J. E., Blanchette C. A., Hovel K., Neilson D., Dugan J., Altstatt J., Nielsen K. \&

519 Bursek J. (2018) Citizen science monitoring of marine protected areas: Case studies and recommendations for integration into monitoring programs. Marine Ecology 39, e12470. Citizen science and wildlife biology: Synergies and challenges. Ethology 124, 365-77. 
Galbraith J. A., Beggs J. R., Jones D. N. \& Stanley M. C. (2015) Supplementary feeding restructures urban bird communities. Proceedings of the National Academy of Sciences, 201501489.

Galloway A. W., Hickey R. J. \& Koehler G. M. (2011) A survey of ungulates by students along rural school bus routes. Society and Natural Resources 24, 201-4.

Galloway A. W., Tudor M. T. \& HAEGEN W. M. V. (2006) The reliability of citizen science: a case study of Oregon white oak stand surveys. Wildlife Society Bulletin 34, 1425-9.

\section{(1)}

Gardiner M. M., Allee L. L., Brown P. M., Losey J. E., Roy H. E. \& Smyth R. R. (2012) Lessons from lady beetles: accuracy of monitoring data from US and UK citizen-science programs. Frontiers in Ecology and the Environment 10, 471-6.

Giles J. \& Parson C. (2001) 'Citizen scientists' at work on the Chicago River. Teaching Geography 26, 77-80.

Henter H. J., Imondi R., James K., Spencer D. \& Steinke D. (2016) DNA barcoding in diverse educational settings: five case studies. Phil. Trans. R. Soc. B 371, 20150340.

Hidalgo-Ruz V. \& Thiel M. (2013) Distribution and abundance of small plastic debris on beaches in the SE Pacific (Chile): a study supported by a citizen science project. Marine environmental research 87, 12-8.

Jones D. (2018) The Birds at My Table: Why We Feed Wild Birds and why it Matters. Cornell University Press.

Kleinke B., Prajzner S., Gordon C., Hoekstra N., Kautz A. \& Gardiner M. (2018) Identifying Barriers to Citizen Scientist Retention When Measuring Pollination Services. Citizen Science: Theory and Practice 3.

Kobori H., Dickinson J. L., Washitani I., Sakurai R., Amano T., Komatsu N., Kitamura W., Takagawa S., Koyama K. \& Ogawara T. (2016) Citizen science: a new approach to advance ecology, education, and conservation. Ecological research 31, 1-19.

Le Féon V., Henry M., Guilbaud L., Coiffait-Gombault C., Dufrêne E., Kolodziejczyk E., Kuhlmann M., Requier F. \& Vaissière B. E. (2016) An expert-assisted citizen science program involving agricultural high schools provides national patterns on bee species assemblages. Journal of insect conservation 20, 905-18. 

Ecologists, educators, and writers collaborate with the public to assess backyard diversity in The School of Ants Project. Ecosphere 5, 1-23.

Matthews C. E., Huffling L. D. \& Benavides A. (2014) The ins \& outs of developing a field-based science project: Learning by lassoing lizards. The American Biology Teacher 76, 320-6.

McKeown R. (2003) Working with K-12 schools: Insights for scientists. Bioscience 53, 870-5.

Nali C. \& Lorenzini G. (2007) Air quality survey carried out by schoolchildren: an innovative tool for urban planning. Environmental monitoring and assessment 131, 201-10.

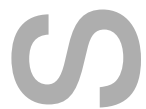

Osborn D. A., Pearse J. S. \& Roe C. A. (2005) Monitoring rocky intertidal shorelines: a role for the public in resource management. In: California and the World Ocean'02: Revisiting and Revising California's Ocean Agenda pp. 624-36.

Parsons A. W., Goforth C., Costello R. \& Kays R. (2018) The value of citizen science for ecological monitoring of mammals. PeerJ 6, e4536.

Pitt A. N. \& Schultz C. A. (2018) Youth-based citizen science monitoring: Case studies from three national forests. Journal of Forestry 116, 109-16.

Pocock M. J., Tweddle J. C., Savage J., Robinson L. D. \& Roy H. E. (2017) The diversity and evolution of ecological and environmental citizen science. PloS one 12, e0172579.

Reedy A. M., Zaragoza D. \& Warner D. A. (2012) Maternally chosen nest sites positively affect multiple components of offspring fitness in a lizard. Behavioral Ecology 24, 39-46.

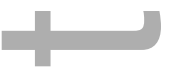

Reynolds S. J., Galbraith J. A., Smith J. A. \& Jones D. N. (2017) Garden bird feeding: insights and prospects from a north-south comparison of this global urban phenomenon. Frontiers in Ecology and Evolution 5, 24.

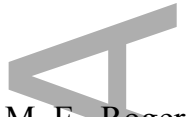

Saunders M. E., Roger E., Geary W. L., Meredith F., Welbourne D. J., Bako A., Canavan E., Herro F., Herron C. \& Hung O. (2018) Citizen science in schools: Engaging students in research on urban habitat for pollinators. Austral Ecology 43, 635-42.

Silvertown J. (2009) A new dawn for citizen science. Trends in ecology \& evolution 24, 467-71. 

educational outreach with scientific discovery. PLoS biology 15, e2001829. participation in environmental research, 179-90.

Vercayie D. \& Herremans M. (2015) Citizen science and smartphones take roadkill monitoring to the next level.

Wals A. E., Brody M., Dillon J. \& Stevenson R. B. (2014) Convergence between science and environmental education. Science 344, 583-4.

Weckel M. E., Mack D., Nagy C., Christie R. \& Wincorn A. (2010) Using citizen science to map HumanCoyote interaction in suburban New York, USA. The Journal of Wildlife Management 74, 1163-71.

Wells C. N. (2010) An ecological field lab for tracking monarch butterflies \& their parasites. The American Biology Teacher 72, 339-44.

Wiggins A. \& Crowston K. (2011) From conservation to crowdsourcing: A typology of citizen science. In: System Sciences (HICSS), 2011 44th Hawaii international conference on pp. 1-10. IEEE. focus. Frontiers in Ecology and the Environment 10, 310-3.

587

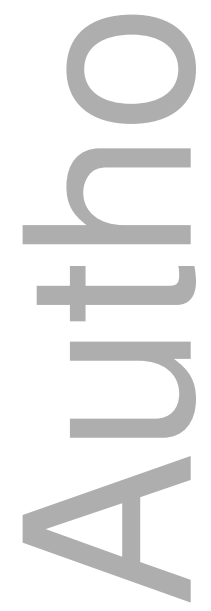




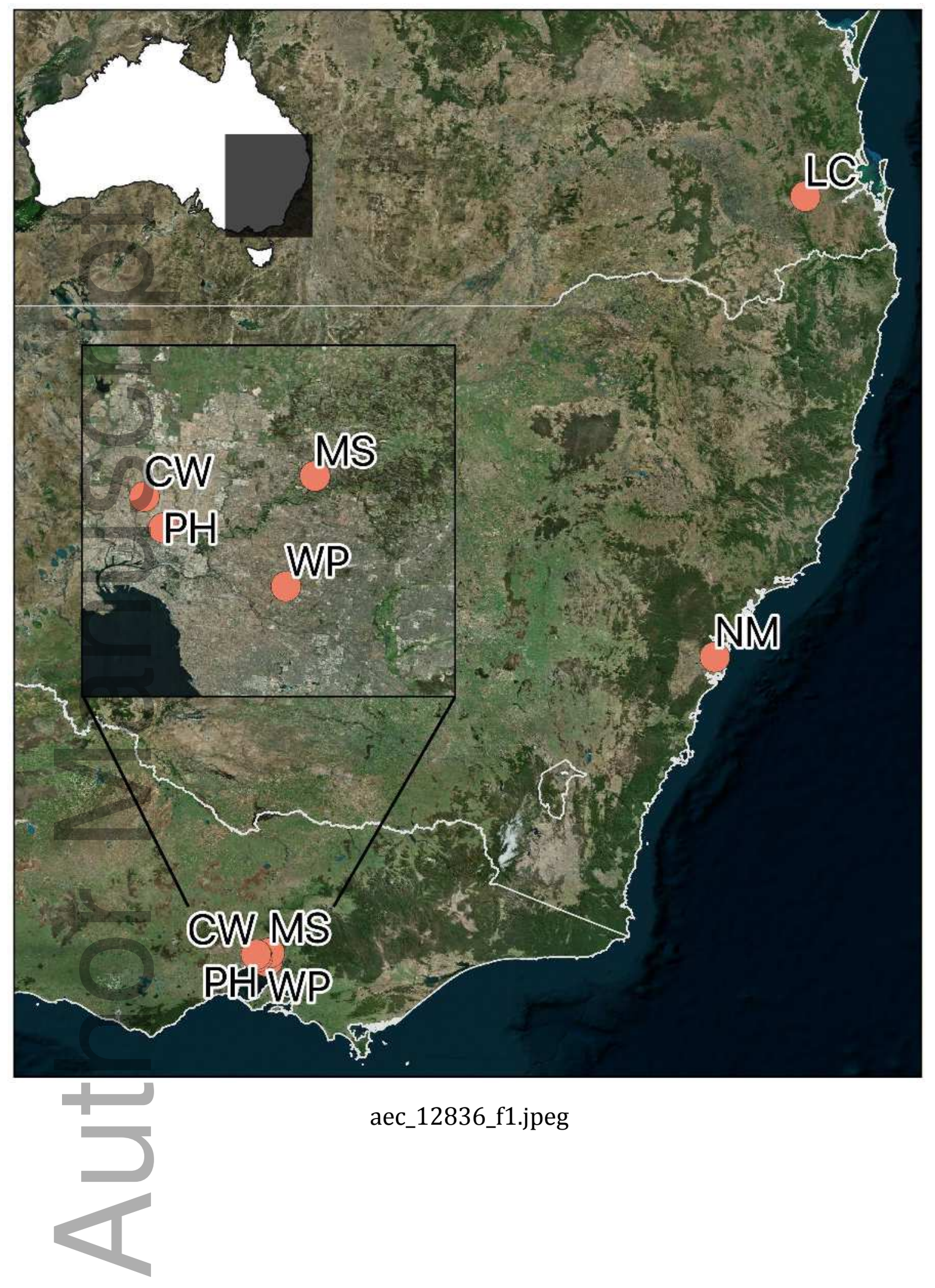

This article is protected by copyright. All rights reserved 


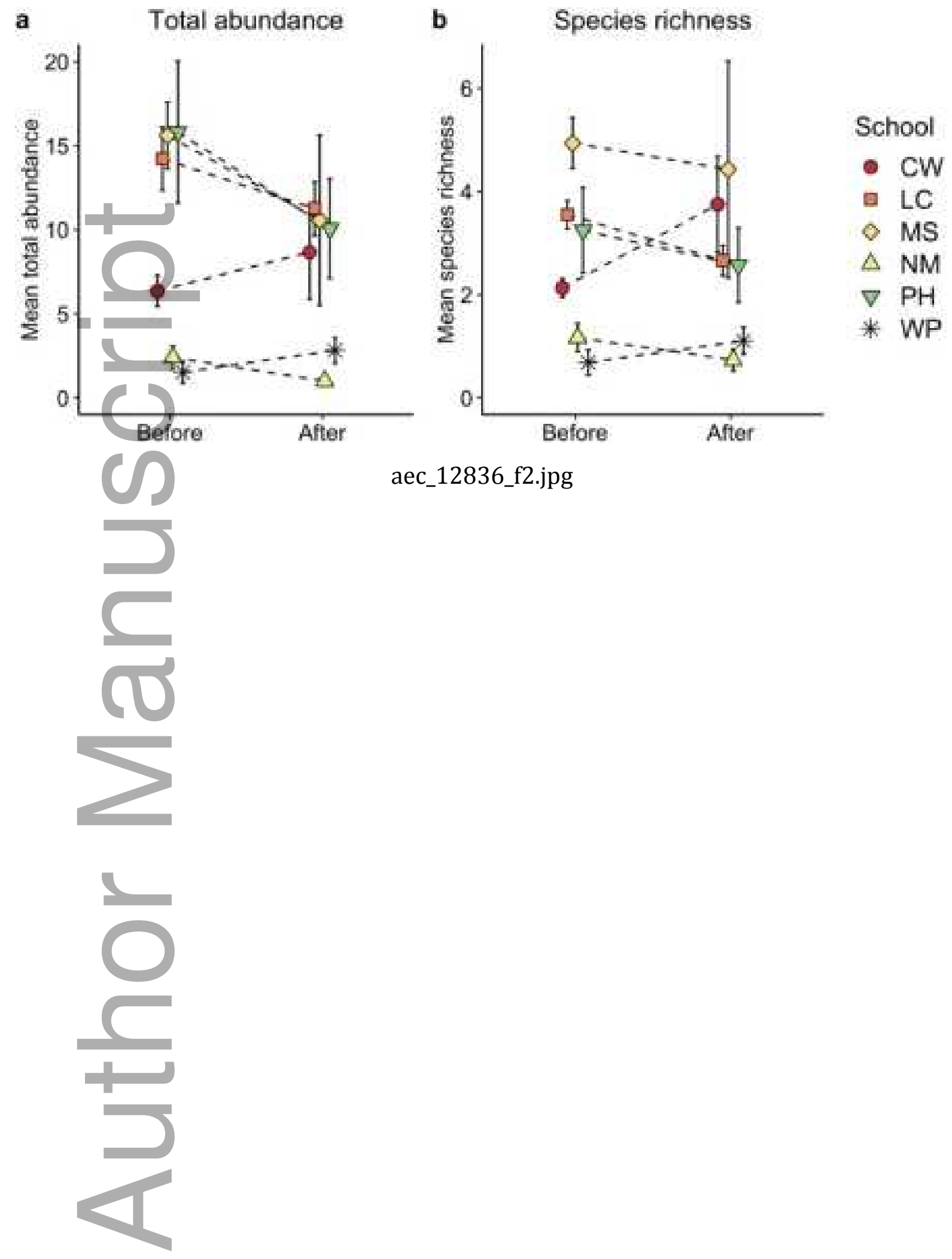

This article is protected by copyright. All rights reserved 


\section{University Library}

\section{- M M N E R VA A gateway to Melbourne's research publications}

Minerva Access is the Institutional Repository of The University of Melbourne

\section{Author/s:}

Soanes, K;Cranney, K;Dade, MC;Edwards, AM;Palavalli-Nettimi, R;Doherty, TS

Title:

How to work with children and animals: A guide for school-based citizen science in wildlife research

\section{Date:}

2019-11-12

\section{Citation:}

Soanes, K., Cranney, K., Dade, M. C., Edwards, A. M., Palavalli-Nettimi, R. \& Doherty, T. S. (2019). How to work with children and animals: A guide for school-based citizen science in wildlife research. AUSTRAL ECOLOGY, 45 (1), pp.3-14. https://doi.org/10.1111/aec.12836.

Persistent Link:

http://hdl.handle.net/11343/286605 